\title{
Opening Dialogue amidst Conflict: Utilizing Young Adult Literature in the Classroom to Combat Bullying
}

$\boldsymbol{H}$ e stepped so close that Darrell could smell his breath, a sickening mixture of onions and cigarette smoke. "What's your name, kid?" he asked.

"I'm Darrell . . . Mercer."

"Darrell . . . Mercer," the boy repeated with a chuckle.

Darrell's name struck them all as funny. They kept saying it over and over in a mocking way. Darrell looked for a way to get away from them, but he was surrounded. Finally, the big kid asked, "You got any money on you, Darrell Mercer?"

"For what?" Darrell asked.

"We thought you'd make us a loan, so we don't put your scrawny butt in that trash dumpster over there," the big one said. His friends started laughing out loud. One kid in an oversized Lakers shirt doubled over, unable to control his laughter.

"He looks like he's going to wet his pants," the kid in the Lakers shirt said, struggling to catch his breath amidst his laughter.

Darrell gave them $\$ 3.25$, all he had. His hands were trembling when he turned over the money.

"Three bucks? That all you got?" The muscular kid demanded. Darrell stared at him in open-mouthed terror. Then, without a word, Darrell tried to walk down the sidewalk past them, but they all moved into his path, blocking him. The large kid raised his finger and poked Darrell's chest, "I'm Tyray Hobbs. I'm a freshman at Bluford, and I run things around here. Hear what I'm sayin'?"

"Yeah," Darrell said, nodding his head. He wanted to go home, not to Uncle Jason's, but back to Philadel- phia. Once again, he tried to move down the sidewalk. This time, the boys stepped aside. But as he hurried to get past them, Tyray stuck his foot out. Unable to step over Tyray's Nikes, Darrell tripped and fell into the gutter. His teeth jammed into his lip when he hit the ground. He could taste the salty blood oozing into his mouth. (Langan 24-26).

This fictional scene from The Bully (Townsend Press, 2001), is actually representative of the real-life experiences of many adolescents. Even with the prevalence of these experiences and numerous reports in the media, adolescents do not often take bullying seriously. However, some striking facts indicate that bullying is definitely a serious matter. According to the United States Health Resources and Services Administration:

- Between 15-25\% of U.S. students are bullied (Nansel, Overpeck, Pilla, Ruan, Simons-Morton, \& Scheidt, 2001).

- Between $15-20 \%$ of U.S. students report they bully others (Nansel, et al., 2001).

- Young people who bully are more likely to be truant or drop out of school (Olweus, 1993).

- Young people who bully are more likely to smoke, drink alcohol, and get into fights (Olweus, 1993).

Many schools across the nation are working hard to introduce anti-bullying programs as a way to combat the problems these figures represent. In the wake of the recent wave of horrific school shootings, school officials have come to realize the full impact bullying can have. It has been estimated that twothirds of students who were involved in school shootings have reported feeling bullied before their 
attacks ("Designing a Safe School" 1). As a reaction to this, almost every state has passed laws requiring schools to develop programs to combat the problem. Colorado, for example, requires districts to have antibullying programs, while Delaware has given

\section{Significantly, the programs}

that emphasized improved interpersonal relation-

ships, as opposed to punitive measures, were

the most successful.

Shockingly, the results

seem to suggest that

while the programs may

have reduced the inci-

dence of bullying, they did

not decrease the numbers

of those engaged in bully-

ing. bullying. The Safe Schools Initiative presented some of the most important findings. One key finding was that "[M] any attackers [involved in recent school violence] felt bullied, persecuted, or injured by others prior to the attack" (Vossekuil, Fein, Reddy, Borum, \& Modzeleski 38). This suggests that anti-bullying efforts have far-reaching implications beyond just preventing bullying. Anti-bullying programs that truly involve a teacher-student dialogue can work to prevent not only bullying, but also more widespread violence such as shootings. One of the suggestions made by the initiative was that "Educators can play a part in prevention by creating an environment where students feel comfortable telling an adult . . . about someone who is considering doing harm to another person, or . . . themselves" (Vossekuil et al., 42). This means that individual teachers can begin to implement measures in the classroom to help prevent bullying. Using young adult literature that students can relate to will go a long way in fostering a comfortable environment to discuss bullying.

\section{Dealing with Bullying in the Context of the Classroom}

Although many anti-bullying programs are effective to a certain degree (17-50\%) (Vossekuil et al., "School Bullying Reduced;" Rigby, Olweus, "Designing a Safe School"), they could be even more powerful if fully integrated into the curriculum. In addition, an approach that focuses on interpersonal/intrapersonal relationships would be the most effective. As Stan Davis, author of Schools Where Everyone Belongs: Practical Strategies to Reduce Bullying, noted, some key components of successful programs dealing with character issues with adolescents are:

1. Respect young peoples' autonomy. We cannot make them change, but we can follow through with consistent consequences. Build supportive relationships so they want to be contributing members of the school; then help the students make the best choices.

2. Maintain young peoples' sense of belonging. Build mentoring relationships and maintain a positive tone in consequences of poor behavior. Students are more likely to take responsibility for negative behaviors, and then change.

3. Teach cause-and-effect thinking and promote conscience development. Help students see 
connections between what they do and what happens to them. Help students discover positive and negative effects of their choices through reflection. Additionally, using questions instead of statements may help students think about their own actions, as opposed to thinking the topic doesn't relate to them (Stop Bullying Now).

An effective and efficient way to cover these three recommendations is to address the issues through open dialogue in the context of the English/Language Arts classroom. In particular, teachers can use young adult literature to engender high interest and increase the participation in class discussions.

\section{Classroom Conversations}

A number of effective ideas and activities can help bring about dialogue focusing on bullying. For example, the teacher should begin by dividing the young adult literature selections into themes related to bullying issues, and then divide the class into literature circle groups to discuss each theme. As part of a unit, teachers should develop lessons that focus on crucial issues. One lesson should focus on emotional reactions students have to the literature in order to help them begin to empathize with both the ones being bullied and the ones doing the bullying. The next lesson should focus on characterization, with the goal of helping students understand what personality traits are prevalent among those being bullied and those doing the bullying. Then teachers should develop a lesson focusing on settings, with objectives related to creating environments more conducive to collaboration. The more students work with each other and see each other as individuals, the less likely it is that bullying will occur. Finally, an important lesson to develop should deal with the specific themes students found in the literature, with the goal of becoming more conscious of the overall cause and effect relationships inherent in bullying situations. Students need to focus on bullying, not on bullies. They need to understand what causes bullying so they can work to prevent it.

A crucial first step to beginning a dialogue is to introduce students to the topic of bullying. Students can take a quiz in order to discover their experiences with bullying. One such example is through the Education World web site. This site includes lessons specifically on bullying that teachers created after the harassment of Muslim and Arab American students following 9/11. The site is "Kids Bullying Kids" at < http://www.educationworld.com/a_lesson/00-2/ lp2055.shtml > . The survey about bullying has been adapted specifically for middle school students and covers students' own experiences. After completing the survey, students then discuss it and explore solutions to the problems. Another survey option aims at both middle and high school students. The Bullying Reality Quiz is also through Education World and is at http:// www.educationworld.com/ a_lesson/00-2/

lp2064.shtml. Designed for both middle level and high school students, this online quiz questions students about school violence and has students create their own quiz on bullying.

After teachers introduce the topic of bullying, it is important that students formulate their own ideas concerning the topic. Using either a semantic word map or a visual representation to explore the term bullying (or perhaps different kinds of bullying) is a way for students to internalize their perceptions of the meanings, implications, and consequences of bullying. The following web sites aid students in generating their own definitions of bullying, understanding what they might do to combat bullying, and discussing the existence of bullying in their own lives:

- www.stopbullyingnow.hrsa.gov. Maintained by the United States Health Resources and Services Administration, this site covers the topic of bullying, what students can do about it, and interactive quizzes, games, and cartoons for youth.

- www.safeyouth.org. Sponsored by the National Youth Violence Prevention Resource Center, this site is a valuable resource for parents, educators, and youth working together to prevent violence against young people. 
- www.no-bully.com. This site is part of the Colorado Anti-Bullying Project and includes information for teachers, parents, and kids. This site provides links to media, a quiz, stories, and other resources.

- www.cyberbully.org. This site digs into a new type of bullying-electronic. This site aims toward educators, parents, and others to deal with this new issue. Sponsored by the Center for Safe and Responsible Internet Use, the group provides resources for professional development, news links, a monthly forum, and a parent's guide to the topic.

\section{Opening the Dialogue through Young Adult Literature}

Once teachers introduce the topic of bullying, it is imperative to give students situations that relate to their lives and hook their interest, allowing them to be engaged in the discussion. Teachers can achieve these goals by having students read young adult literature, which will, in turn, open up the conversations within the context of the English/language arts classroom and its curriculum. To achieve this goal, it is important to note the plethora of young adult books dealing with tough topics, including bullying. The following list of books all deal with some aspect of bullying:

\section{Middle School/Junior High School}

\author{
Friends and Family \\ Drowning Anna, by Sue Mayfield (upper middle) \\ The Skin I'm In, by Sharon Flake \\ The Girls, by Amy Goldman Koss \\ The Watsons Go to Birmingham, 1963, by Christopher \\ Paul Curtis \\ School \\ Crash, by Jerry Spinelli \\ Macaroni Boy, by Katherine Ayres \\ Hoot, by Carl Hiaasen \\ Identity \\ The Misfits, by James Howe \\ Stargirl, by Jerry Spinelli
}

\section{High School}

\section{Date Violence and Sexual Harassment}

Speak, by Laurie Halse Anderson

Breathing Underwater, by Alex Flinn
The Battle of Jericho, by Sharon Draper

Out of Control, by Paula Fox Mazer

School Harassment

The Chocolate War, by Robert Cormier

Whale Talk, by Chris Crutcher

Staying Fat for Sarah Byrnes, by Chris Crutcher

Breaking Point, by Alex Flinn

Inventing Elliott, by Graham Gardner

Endgame, by Nancy Garden

Alt Ed, by Katherine Atkins

Friends

Godless, by Pete Hautman

Drowning Anna, by Sue Mayfield

Shattering Glass, by Gail Giles

What Happened to Lani Garver, by Carol Plum-Ucci

The Body of Christopher Creed, by Carol Plum-Ucci

Jake Riley: Irreparably Damaged, by Rebecca Fjelland

Davis

It is important to address various issues with the students as they read the texts. Pulling in news articles concerning current events related to the themes outlined above will facilitate open discussion and dialogue in the classroom. In addition, having students write and share responses to what they are reading is a strong addition to classroom conversations. For example, it is valuable to begin on the emotional level with questions such as:

1. What is your first reaction to the work?

2. What feelings and/or emotions does the work evoke in you?

3. What character(s) do you particularly like or dislike?

4. Do any of the characters remind you of people you know?

5. What memory does the work help you recall?

6. Have you been in a similar situation (Bushman, 129)?

Next, the teacher moves to the intellectual level with questions like:

1. Would you change the ending of the work? Why or why not? If so, how?

2. What fears and/or concerns do you have for the characters?

3. What is the major point of the work?

4. What is your final reaction to the work (Bushman, 130)? 


\section{Wrapping Up the Unit}

Within this unit, it is important to include situations where students react to conflict. Education World offers a link to scenarios, allowing middle school students to discuss various ways to react to conflict effectively at http://www.educationworld.com /a_lesson/00-2/lp2059.shtml. Although this activity is for younger adolescents, teachers can transfer situations to the high school level or adapt the activities to meet the needs of students in their school. A strong culminating activity for such a unit would be to have the students write. After opening up the dialogue on this topic, allowing students to dig further into the issue would allow them to demonstrate what they have learned through the unit. The teacher can use the following prompts to foster critical thinking:

1. In a short story, examine one of the issues discussed in relationship to the literature we read in class. You might use a similar scenario or story line as was presented in the work(s) you read. Be sure to use your imagination and create a situation as you would like to see it, or from a different point of view. Include the five elements of setup, conflict, struggle, outcome, and meaning.

2. In a poem, express some of the feelings you have toward the literature you read or issues presented in the literature. Use your five senses and imagery to express the feelings. Something like "a tear fell down my cheek" would be better than "I felt sad."

3. In a newspaper article, discuss one of the issues that came up in your literature circle. Use this forum to express your opinions about what happened in the book you read, as well as reporting the facts. You may use one of the articles we read in class as a model.

4. Create a PowerPoint, webpage or poster outlining the important issues we discussed in class to show what people can do to deal with these issues. Be sure to include background information your audience might need, the issues raised by the readings and discussions, and your plan of action to deal with these issues.

\section{Conclusions}

Certainly, bullying is a significant problem in schools in this country and around the world. As many as $25 \%$ of students are bullied on a daily basis, mostly verbally and emotionally. In addition, bullying can lead to other problems such as drug abuse, poor school performance, and violence such as school shootings. This being the case, many school officials have responded with anti-bullying programs. These programs have been marginally successful. Not surprisingly, teachers are not always included as much as they could be, which no doubt leads to this marginal success. In addition, the programs in place do not necessarily affect the students who are engaged in bullying in a positive way. This points to the fact that all students involved in bullying incidents, including the bullies, need to be involved in a dialogue about how to prevent bullying.

If the most successful programs are only $50 \%$ effective, then what can teachers and administrators do about the other $50 \%$ of students they are not reaching? An integrated program of study can reach all of the students in a class. Teachers can use young adult literature, with its high interest and high relevance levels, to open up an ongoing dialogue among students and teachers concerning the real issues behind bullying. It is not enough to punish the "bullies," because this action does not fully address the problem. People bully others for a reason. Conversely, there may be reasons people feel powerless in the face of bullying. If teachers and administrators bring these kinds of issues into the open, then schools can come closer to significantly reducing the occurrences of bullying, and in turn, make our schools a better place to learn and grow.

Kenan Metzger is an assistant professor of English Education at Ball State University. He teaches middle school methods and young adult literature to preservice teachers. His research interests include the teaching of writing, creating culturally relevant curriculum, young adult literature for diverse populations and performance evaluations.

Jill Adams is an assistant professor of English at Metropolitan State College of Denver. She teaches freshman composition, creative writing, young adult literature, and secondary methods in English education. Her research interests include the teaching of writing, the impact of technology on reading and writing, reading habits of secondary students, young adult literature, and the effectiveness of academic online discussion boards. 


\section{Works Cited or Consulted}

Anderson, Laurie Halse. Speak. New York: Farrar, Straus, and Giroux, 1999.

Atkins, Catherine. Alt Ed. New York: Penguin, 2003.

Ayres, Katherine. Macaroni Boy. New York: Delacorte, 2003.

"Bullying." National Youth Violence Prevention Resource Center. 27 Jan. 2006. http://www.safeyouth.org/scripts/teens/ bullying.asp.

"Bullying Reality Quiz." Education World. 27 Jan. 2006. http:// www.educationworld.com/a_lesson/00-2/lp2064.shtml.

Bushman, John. Teaching English Creatively. Springfield, IL: Charles C. Thomas, 2001.

"Cyberbullying". Center for Safe and Responsible Internet Use. 27 Jan. 2005. http://www.cyberbully.org/.

Cormier, Robert. The Chocolate War. New York: Knopf, 1974.

Crutcher, Chris. Staying Fat for Sarah Byrnes. New York: HarperCollins, 1993.

-_- Whale Talk. New York: Greenwillow, 2001.

Curtis, Christopher Paul. The Watsons Go to Birmingham1963. New York: Delacorte, 1995.

Davis, Rebecca Fjelland. Jake Riley: Irreparably Damaged. New York: Harper Collins, 2003.

Davis, Stan. Schools Where Everyone Belongs: Practical Strategies to Reduce Bullying. Champaign, IL: Research Press, 2005.

Davis, Stan. Stop Bullying Now! Presenting Practical ResearchBased Strategies to Reduce Bullying in Schools. 2002. 30 Dec. 2005. http://stopbullyingnow.com.

"Designing a Safe School." Healthy Choices. Birmingham, MI: Bridge Communications, 2001. 13 Jan. 2006. http:// www.bridge-comm.com/site/mgh_hn/fall2001/safe.htm.

Draper, Sharon. The Battle of Jericho. New York: Athenaeum, 2003.

Flake, Sharon. The Skin I'm In. New York: Jump at the Sun, 2000.

Flinn, Alex. Breaking Point. New York: HarperCollins, 2002.

-_- Breathing Underwater. New York: HarperCollins, 2001.

Garden, Nancy. Endgame. New York: Harcourt, 2006.

Gardner, Graham. Inventing Elliott. New York: Penguin, 2003.

Giles, Gail. Shattering Glass. Brookfield, CT: Roaring Brook Press, 2002.

Glasgow, Jacqueline, ed. Strategies for Engaging Young Adult Readers: A Social Themes Approach. Norwood, MA: Christopher-Gordon Publishers, 2005.

Hautman, Pete. Godless. New York: Simon and Schuster, 2004.

Hiaasen, Carl. Hoot. New York: Alfred A. Knopf, 2002.

Howe, Carl. The Misfits. New York: Athenaeum, 2001.
Kids Bullying Kids. Education World. 27 Jan. 2006. http:// www.educationworld.com/a_lesson/00-2/lp2055.shtml. Koss, Amy Goldman. The Girls. New York: Dial Books, 2000. Langan, Paul. The Bully. West Berlin, NJ: Townsend, 2002. Mayfield, Sue. Drowning Anna. New York: Hyperion, 2002. Mazer, Norma Fox. Out of Control. New York: Avon, 1993.

Nansel, Tonja R., Overpeck, Mary, Pilla, Ramani S., Ruan, W. June, Simons-Morton, Bruce, Scheidt, Peter. "Bullying Behaviors among U.S. Youth: Prevalence and Association with Psychosocial Adjustment." Journal of the American Medical Association, 285.16 (2001).

Olweus, Dan. Bullying at School: What We Know and What We Can Do. Cambridge, MA: Blackwell Publishers, 1993.

Plum-Ucci, Carol. The Body of Christopher Creed. San Diego: Harcourt, 2000.

Plum-Ucci, Carol What Happened to Lani Garver. New York: Harcourt, 2002.

Reacting to Conflict. Education World. 27 Jan. 2006. http:// www.educationworld.com/a_lesson/00-2/lp2059.shtml.

Rigby, Ken. How Successful are Anti-Bullying Programs for Schools? Paper presented at The Role of Schools in Crime Prevention Conference. Melbourne, Australia: Department of Education, 2002.

"School Bullying Reduced by Program." Media release: The University of Melbourne, Australia, 2003. 13 Jan. 2006 http: //uninews.unimelb.edu.au/articleid_436.html.

Stamp Out Bullying. Colorado Anti-Bullying Project. 27 Jan. 2006 http://www.no-bully.com/.

Stop Bullying Now! Education World. 2005. 31 Dec. 2005. http://www.educationworld.com/a_lesson/lesson/ lesson 191.shtml.

Stop Bullying Now! Take a Stand. Lend a Hand. U.S. Department of Health and Human Services Health Resources and Services Administration. 31 Dec. 2005 http:// stopbullyingnow.hrsa.gov/index.asp?area=effects.

Stop the Bullying in Life and in Young Adult Literature. Ohio Resource Center for Mathematics, Science, and Reading. 11 Dec. 2005. http://www.ohiorc.org/adlit/units/ units_each.aspx?unitID $=3$.

Spinelli, Jerry. Crash. New York: Dell Yearling, 1996.

-_- Stargirl. New York: Knopf, 2000.

Vossekuil, Bryan, Fein, Robert A., Reddy, Marissa, Borum, Randy, \& Modzeleski, William. The Final Report and Findings of the Safe Schools Initiative: Implications for the Prevention of School Attacks in the United States. Washington D.C. U.S. Secret Service and U.S. Department of Education, 2002. 